\title{
A STUDY OF TWO IMMUNOLOGICAL TESTS IN THE DIAGNOSIS AND PROGNOSIS OF HYDATID DISEASE
}

\author{
C. M. Patricia Bradstreet \\ Standards Laboratory for Serological Reagents, Colindale, London
}

SINCE the early years of this century the complement-fixation test (CFT) (Ghedini, 1906) and the intradermal test (Casoni, 1911) have both been used extensively for the diagnosis of hydatid disease and there have been many publications of the results of their use (table I). The variations in the percentage of positive results reported probably arose because of the use of different antigen preparations and different methods of performing the tests: hydatid fluids were procured from man, sheep and other infected animals, and were used as whole fluids, undiluted and diluted, or as alcoholic, acid or other extracts; different quantities of fluid were injected in the skin test, and a great number of modifications in technique, which would affect the sensitivity of the test, were used in complement fixation.

Some years ago Bensted and Atkinson (1953) redirected attention to the need for standardisation of the reagents to be used in complement-fixation and intradermal tests, and in a small number of cases in which the diagnosis of hydatid disease was confirmed they found that the two tests were reliable and that they showed good correlation. Since then the tests have been used extensively in Britain. During the years 1957 to 1967 over 9000 skin-test doses of hydatid fluid have been issued and nearly 3500 CFTs have been performed on cases of suspected hydatid disease.

This paper presents the results obtained during this time. From them a reappraisal is made of the reliability of the tests for the diagnosis and prognosis of hydatid disease, and additional studies are also reported on the basis of the results of all the CFTs that have been performed.

\section{MATERIALS AND METHODS}

Preparation of antigens. Antigens used in the tests consisted of hydatid cyst fluids obtained under sterile conditions from man or sheep. They were sent to the Standards Laboratory, Colindale, in sterile containers. Only those fluids abundant in scolices were selected for use as antigens (Fairley, 1922). They were centrifuged at about 1500 r.p.m. for $10 \mathrm{~min}$. to remove scolices and cellular debris and the resulting supernatant fluids, after the addition of merthiolate (1 in 10,000), were stored at $4^{\circ} \mathrm{C}$ until used for the CFT or the skin test. Fluid from either source was used for each test, depending upon availability at the time. Sheep fluid was obtained from Cyprus and New Zealand; one human fluid came from Iraq; all others were from human cases in Britain.

Standardisation of antigens for use in the CFT. Hydatid fluid was standardised by means of chessboard titrations according to the technique described by Bradstreet and Taylor (1962) with individual sera from several cases of human hydatid disease. Four units (HD50)

Received 5 Feb. 1969; accepted 24 Mar. 1969.

J. MED. MCROBIOL.-VOL. 2 (1969) 
of complement were used and fixation took place at $4^{\circ} \mathrm{C}$ overnight. From each test the dilution of hydatid fluid showing most fixation with the highest dilution of serum, that is, the optimal dilution of hydatid fluid, was noted and a dilution suitable for general use selected.

Standardisation of antigens for use in intradermal tests. The review of Hariri, Schwabe and Koussa (1965) indicates that different antigens are involved in the demonstration of skin sensitivity and in the fixation of complement, and this is confirmed by Magath (1959) who

\section{TABLE I}

A comparison of the percentages of positive results obtained by different workers with the complement-fixation test and the intradermal test in cases of hydatid disease

\begin{tabular}{|c|c|c|c|}
\hline \multicolumn{2}{|c|}{$\begin{array}{l}\text { Percentage of positive } \\
\text { results with }\end{array}$} & \multirow{2}{*}{ Reference } & \multirow{2}{*}{$\begin{array}{l}\text { Geographica } \\
\text { area }\end{array}$} \\
\hline $\begin{array}{l}\text { Complement- } \\
\text { fixation } \\
\text { test }\end{array}$ & $\begin{array}{c}\text { Intradermal } \\
\text { (Casoni) } \\
\text { test }\end{array}$ & & \\
\hline $\begin{array}{r}73 \\
43 \\
93 \\
20 \\
\ldots \\
100 \\
28 \\
93 \\
63 \\
77 \\
36 \\
62 \\
55 \\
57\end{array}$ & $\begin{array}{r}\cdots \\
\cdots \\
\ldots \\
\dddot{90} \\
75 \\
75 \\
84 \\
\dddot{9} \\
98 \\
100 \\
85 \\
87 \\
86 \\
85 \\
\cdots \\
\dddot{86} \\
66 \\
89 \\
\dddot{74} \\
71 \\
85\end{array}$ & $\begin{array}{l}\text { Weinberg, } 1913 \text { (cited by Fairley, 1922) } \\
\text { Weinberg, } 1913 \text { (cited by Fairley, 1922) } \\
\text { Zapelloni, } 1915 \text { (cited by Fairley, 1922) } \\
\text { Fairley, 1922 } \\
\text { Kellaway, } 1925 \\
\text { Kellaway and Fairley, } 1932 \\
\text { Fairley and Kellaway, 1933 } \\
\text { Pontano, } 1920 \text { (cited by Hiles, 1926a) } \\
\text { Ithurrat and Calcagno, 1922 (cited by Hiles, 1926a) } \\
\text { Ithurrat and Calcagno, 1923 (cited by Hiles, 1926b) } \\
\text { Mogena, 1924 (cited by Hiles, 1926a) } \\
\text { Trenti, } 1924 \text { (cited by Hiles, 1926a) } \\
\text { Magath, 1959 } \\
\text { Imari, } 1962 \\
\text { Jonathan, } 1960 \\
\text { Giunchi, } 1960 \text { (cited by Kagan et al., 1966) } \\
\text { Bocchetti, 1951 (cited by Kagan } \text { et al., 1966) } \\
\text { Bensted and Atkinson, 1953 } \\
\text { Myers, } 1960 \\
\text { Garabedian } \text { et al., 1959 } \\
\text { Kagan, Allain and Norman, 1959 } \\
\text { Arabatzis and Papapanagiotou, } 1963 \\
\text { Abou-Daoud, 1965 } \\
\text { Mirdamadi and Saadatzadeh, } 1968\end{array}$ & $\begin{array}{l}\text { Europe } \\
\text { Europe } \\
\text { Europe } \\
\text { Australia } \\
\text { Australia } \\
\text { Australia } \\
\text { Australia } \\
\text { Europe } \\
\text { Europe } \\
\text { Europe } \\
\text { Europe } \\
\text { Europe } \\
\text { N. America } \\
\text { Asia } \\
\text { Europe } \\
\text { Europe } \\
\text { Europe } \\
\text { Europe } \\
\text { Australia } \\
\text { Asia } \\
\text { N. America } \\
\text { Europe } \\
\text { Asia } \\
\text { Asia }\end{array}$ \\
\hline
\end{tabular}

$\ldots=$ Not done or not reported.

obtained positive results in intradermal tests with fluids that had been Seitz-filtered. However, since the potency of a fluid for both tests is proportional to the number of scolices present (Fairley, 1922), the result of a CFT may reflect the amount of skin-test antigen that is also present. For standardising hydatid fluid for use in the skin test, a chessboard titration was therefore done and the optimal dilution of the fluid noted. During the first $5 \mathrm{yr}$ of this study from 1957 to 1962 , undiluted fluid was issued. In the belief that a more specific reaction might be obtained if hydatid fluid was used diluted, a small trial was undertaken. With a batch with an optimal dilution in the CFT of 1 in 30 , parallel tests were performed on 9 patients with hydatid fluid used undiluted and at a dilution of 1 in 10. Although an enhanced specificity of the diluted antigen was not demonstrated, reactions obtained with both fluids were closely similar. Thereafter, fluids for intradermal tests were issued at dilutions corresponding to three times the strength of the optimum concentration used in the CFT. 
Whenever it was possible before the issue of a new antigen, skin tests were carried out on a number of persons known to have hydatid disease and on negative controls.

Thus, there were three criteria employed for evaluation of Casoni antigen: (a) the presence of scolices in the fluid, $(b)$ the potency of fluid observed in a CFT, and $(c)$ the results of skin tests in known positive and negative cases.

The complement-fixation test. With few exceptions, blood was taken from patients before the skin test was done. Serum specimens were usually tested on the day of arrival at the laboratory and those not tested within 24 to $48 \mathrm{hr}$ were stored at $4^{\circ} \mathrm{C}$. Before titration, samples were heated at $56^{\circ} \mathrm{C}$ for $30 \mathrm{~min}$. Initially, all sera were tested in a single row of doubling dilutions from 1 in 2 to 1 in 128 with the optimal dilution of hydatid fluid by a procedure similar in other respects to that used in the standardisation of the fluid. Those sera showing zoning or incomplete fixation, and a small number of positive sera, were also retitrated in chessboard systems.

The intradermal test. The following instructions for the performance and reading of the skin test were sent with each ampoule issued: "Inoculate $0.15 \mathrm{ml}$ of the hydatid fluid into the skin on the outer half of the upper arm $10-15 \mathrm{~cm}$ above the elbow joint. A similar quantity of sterile saline should be injected as a control $3-4 \mathrm{~cm}$ above. A positive reaction is characterised by an immediate and often by a delayed response. Immediate response. A wheal appears in $10 \mathrm{~min}$. or so, reaches its maximum in $30 \mathrm{~min}$., and fades in about $1 \mathrm{hr}$; it is usually surrounded by a wide zone of erythema. The diameter of the wheal should be at least $20 \mathrm{~mm}$. Delayed response. This appears in about $6 \mathrm{hr}$ and lasts for 18-24 hr. It consists of infiltration or oedema at least $40 \mathrm{~mm}$ in diameter. Redness may be present, but it is unimportant. A delayed response is met with in only 50-60 per cent. of uncomplicated preoperative cases".

\section{The investigations}

Sera from all parts of Britain were tested in CFTs in the Standards Laboratory by 4 technicians specially trained in setting up the test, and the majority of the tests were read by the author.

Requests for the skin-test antigen were received also from all parts of Britain. Almost all were required for patients under investigation in hospitals, and the tests were therefore performed by a large number of different medical practitioners. Evaluation of the two tests in diagnosis is based upon known results in 1081 patients on whom they were both performed. Of these, 159 were treated surgically, and a hydatid cyst was found to be present in 101 cases. From the results of the tests in these 159 cases their reliability in patients in whom surgery had or had not confirmed the presence of a cyst was studied. From these cases were also studied the results of the use in intradermal tests of diluted and undiluted hydatid fluids, and of hydatid fluids obtained from sheep and human sources. From all 1081 cases, correlation of the two tests was sought by studying (i) the number of positive skin tests in relation to the titres of antibody detected in the CFT, and (ii) the serum antibody titres of those patients with positive and negative skin tests.

As negative controls in the CFT, 90 sera from patients believed never to have suffered from hydatid disease were tested: these included 50 specimens from females in early pregnancy and 40 from males in hospital with acute infections. All the sera for this purpose came from the London area.

To investigate the results of the skin test in healthy persons, two small surveys were carried out (Thomas, 1966): one in Breconshire, where the incidence of the disease is high, and the other in Cardiganshire, where it is uncommon. Although the test populations were not identical in terms of age, sex and occupation, all individuals tested were young active members of a farming community who were or who had at some time been closely associated with the land or with animals. It was possible to obtain sera from only 8 of those giving a positive result in the skin test. These and second specimens collected from the same persons 6 mth later were tested by complement fixation.

The value of the CFT in prognosis was studied in 37 patients whose sera were tested at intervals following operation. 
Further studies based on results of all the CFTs performed in the laboratory were made: (1) to ascertain from the results of chessboard titrations $(a)$ the variation in the optimal dilution of five batches of hydatid fluid in tests with 304 sera that showed zoning or incomplete fixation in initial routine tests, and $(b)$ any variation in titre of 18 sera when each was tested with a number of different batches of hydatid fluid; (2) to obtain epidemiological information on $(a)$ the frequency of infection in various situations in the body and the corresponding antibody titre in 129 patients in whom the site of the cyst was reported, and $(b)$ the possible prevalence of infection in different areas of Britain.

TABLE II

Results of both tests in cases investigated by surgery

\begin{tabular}{|c|c|c|c|}
\hline \multirow{2}{*}{$\begin{array}{l}\text { Presence of cyst and } \\
\text { no. of cases }\end{array}$} & \multirow{2}{*}{ Test } & \multicolumn{2}{|c|}{ Positive result } \\
\hline & & Number & Per cent. \\
\hline \multirow[t]{2}{*}{ Confirmed (101 cases) } & Intradermal test & 66 & 66 \\
\hline & $\begin{array}{l}\text { CFT } \\
\text { Titre: } 1 \text { in } 2 \text { or more } \\
\begin{aligned} 1 \text { in } 4 \text { or more } \\
1 \text { in } 8 \text { or more } \\
1 \text { in } 16 \text { or more }\end{aligned}\end{array}$ & $\begin{array}{l}93 \\
86 \\
81 \\
68\end{array}$ & $\begin{array}{l}93 \\
86 \\
81 \\
68\end{array}$ \\
\hline \multirow[t]{2}{*}{ Not confirmed (58 cases) } & Intradermal test & 24 & 41 \\
\hline & $\begin{array}{l}\text { CFT } \\
\text { Titre: } 1 \text { in } 2 \text { or more } \\
\begin{aligned} 1 \text { in } 4 \text { or more } \\
1 \text { in } 8 \text { or more } \\
1 \text { in } 16 \text { or more }\end{aligned}\end{array}$ & $\begin{array}{l}38 \\
27 \\
24 \\
16\end{array}$ & $\begin{array}{l}66 \\
47 \\
42 \\
28\end{array}$ \\
\hline
\end{tabular}

\section{RESULTS}

The results of the two tests on 101 patients from whom cysts were removed show that only 66 per cent. gave a positive skin test, whereas 93 per cent. had a titre of 1 in 2 or more in the CFT. In 58 patients in whom at operation there was no evidence of hydatid disease, 24 ( 41 per cent.) were positive in the skin test and 38 ( 66 per cent.) had titres of 1 in 2 or more for complement-fixing antibodies (table II).

The results of the CFT on the control sera (table III) showed that 84 per cent. had no detectable antibody, a further 13 per cent. had low titres of 1 in 2 or 1 in 4 , and only one serum ( 1.1 per cent.) had a titre greater than 1 in 8 .

In table IV, which shows the results of the intradermal test on healthy persons in two Welsh counties, it is seen that a substantially larger proportion of persons living in Breconshire, where hydatid disease is common, had a positive result compared with those in Cardiganshire. Complement-fixing antibody found in first specimens of sera from patients giving positive skin-test results had almost completely disappeared from second specimens collected 6 mth later. Antibody present in the first specimens probably resulted from 
the stimulating effect of the skin test in subjects who had had previous contact with hydatid antigen.

TABLE III

A survey of complement-fixing antibodies to hydatid antigen in the sera of 90 normal persons

\begin{tabular}{c|c|c}
\hline $\begin{array}{c}\text { Titre of } \\
\text { complement-fixing } \\
\text { antibody }\end{array}$ & $\begin{array}{c}\text { Number of } \\
\text { subjects }\end{array}$ & $\begin{array}{c}\text { Percentage } \\
\text { of total }\end{array}$ \\
\hline$<1$ in 2 & 76 & $84 \cdot 0$ \\
1 in 2 & 6 & $6 \cdot 8$ \\
1 in 4 & 5 & $5 \cdot 9$ \\
1 in 8 & 2 & $2 \cdot 2$ \\
1 in 16 & 1 & $1 \cdot 1$ \\
\hline Total. & 90 & $100 \cdot 0$ \\
\hline
\end{tabular}

TABLE IV

Results of immunological tests on persons in two Welsh counties

A. Results of intradermal tests

\begin{tabular}{|c|c|c|c|c|}
\hline County & & Number & Positive & Per cent. \\
\hline Breconshire & . & 62 & 12 & $19 \cdot 5$ \\
\hline Cardiganshire & . & 59 & 1 & $1 \cdot 7$ \\
\hline
\end{tabular}

B. Results of complement-fixation tests on sera from 8 persons with positive skin tests

\begin{tabular}{c|c|c}
\hline & \multicolumn{2}{|c}{ Complement-fixing antibody titre } \\
\cline { 3 - 3 } Patient no. & 1st specimen & 2nd specimen \\
\hline 1 & Negative & Negative \\
\hline 2 & 1 in 8 & Negative \\
3 & Negative & 1 in 2 \\
4 & 1 in 8 & Negative \\
5 & 1 in 8 & 1 in 2 \\
6 & 1 in 2 & Negative \\
7 & 1 in 2 & Negative \\
8 & 1 in 2 & Negative \\
\hline
\end{tabular}

Good correlation was shown between positive skin tests and raised titres of complement-fixing antibody: the proportion of positive skin-test results rose steadily as the antibody titres rose (fig. 1).

This contrasts with the poor correlation between detectable antibody and positive skin tests: only 55 per cent. of 321 patients with positive skin tests 
had a titre of antibody in the CFT, even if those with titres as low as 1 in 2 and 1 in 4 are included; and 32 per cent. of 760 patients with negative skin tests had complement-fixing antibodies in their sera (table V).

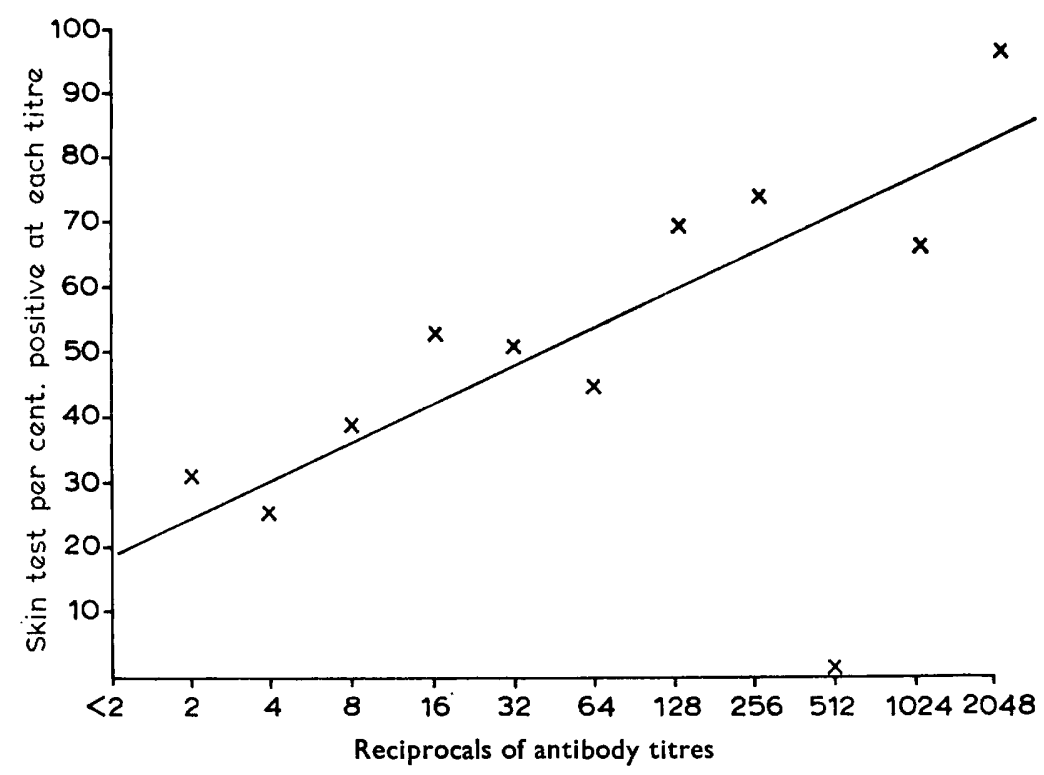

FIg. 1.-Relation between antibody titre and skin test result in 1081 cases.

The results of skin tests performed with diluted and undiluted fluids showed little difference in patients with a cyst, but in patients in whom no cyst was found 54 per cent. had a positive skin test with undiluted fluids, whereas

TABLE V

Results of complement-fixation tests in relation to intradermal test results

\begin{tabular}{c|c|c|c|c}
\hline \multirow{2}{*}{$\begin{array}{c}\text { Number of } \\
\text { subjects tested }\end{array}$} & $\begin{array}{c}\text { Intradermal } \\
\text { test result }\end{array}$ & \multicolumn{2}{|c}{ Complement-fixation test } \\
\cline { 2 - 4 } & Titre & Number & Per cent. \\
\hline 321 & Positive & $\geqq 1$ in 2 & 176 & 55 \\
\hline 760 & Negative & $<1$ in 2 & 518 & 68 \\
\hline
\end{tabular}

38 per cent. were positive with fluids that had been diluted (table VI). This table also shows that in this series a larger proportion of positive results was obtained with diluted sheep fluid than with diluted human fluid both in patients with cysts and in patients in whom no cysts were found at operation.

In the study of 37 cases after surgical treatment, some specimens of sera were submitted before and after operation whereas others were submitted in 
the post-operation period only. No patient in this series was tested continuously through a number of infections, although several patients gave a history of one or more previous operations for the removal of a cyst. The median titres of all sera examined in CFTs are presented in fig. 2.

TABLE VI

Results of intradermal tests in patients treated surgically

\begin{tabular}{|c|c|c|}
\hline \multirow{2}{*}{$\begin{array}{l}\text { Details of hydatid fluid } \\
\text { used }\end{array}$} & \multicolumn{2}{|c|}{ Positive results in patients } \\
\hline & with hydatid cysts & with no hydatid cysts \\
\hline $\begin{array}{l}\text { Undiluted fluid } \\
\text { Sheep or human (1957-61) }\end{array}$ & 29 in 45 (66 per cent.)* & 7 in 13 (54 per cent.) \\
\hline $\begin{array}{l}\text { Diluted fluid } \\
\text { Human }(1962-64) \text {. } \\
\text { Sheep }(1965-66) \\
\text { Total }(1962-66)\end{array}$ & $\begin{array}{l}25 \text { in } 40(63 \text { per cent. }) \\
12 \text { in } 16(75 \text { per cent. }) \\
37 \text { in } 56(66 \text { per cent.) }\end{array}$ & $\begin{array}{r}5 \text { in } 22 \text { ( } 23 \text { per cent.) } \\
12 \text { in } 23 \text { (52 per cent.) } \\
17 \text { in } 45 \text { ( } 38 \text { per cent.) }\end{array}$ \\
\hline
\end{tabular}

* Number positive out of number tested; percentage positive given in brackets.

It can be seen that following leakage of hydatid fluid during operation, the median antibody titre rose at first, then gradually fell until in many cases no

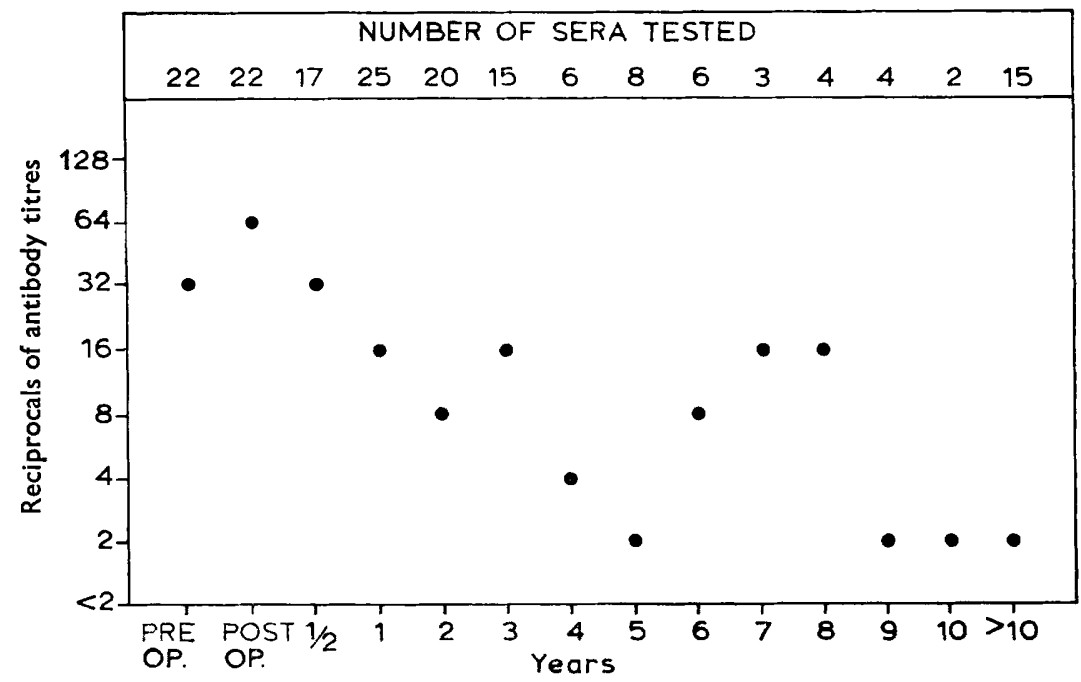

Fig. 2.-Median antibody titres of sera from 37 cases treated by surgery.

antibody was detected after 7-10 yr. However, a few patients many years after operation maintained quite high static titres of 1 in 16 and 1 in 32 (accounting for median titres of 1 in 8 and 1 in 16) with no apparent sign of retained infection or reinfection. There were two cases in this series whose sera in 
consecutive tests several years after operation showed substantial rises in titre, one from 1 in 8 to 1 in 256 and another from 1 in 16 to 1 in 64 . The former patient was reported to be clinically well during this period and no further tests were performed; the titre of the second patient subsequently returned to 1 in 16 , and he also was clinically well throughout this time. In all other patients studied, antibody levels fell and then remained stable or became negative. Table VII shows that, in chessboard titrations of 304 selected sera with five different batches of hydatid fluids, all fluids showed a wide variation in their optimal dilution, ranging sometimes from 1 in 3 to more than 300 . It was observed in these tests that titres obtained with suboptimal dilutions of hydatid fluid were sometimes considerably reduced or of no diagnostic significance.

TABLE VII

Optimal dilutions of five antigens in chessboard titrations with 304 sera

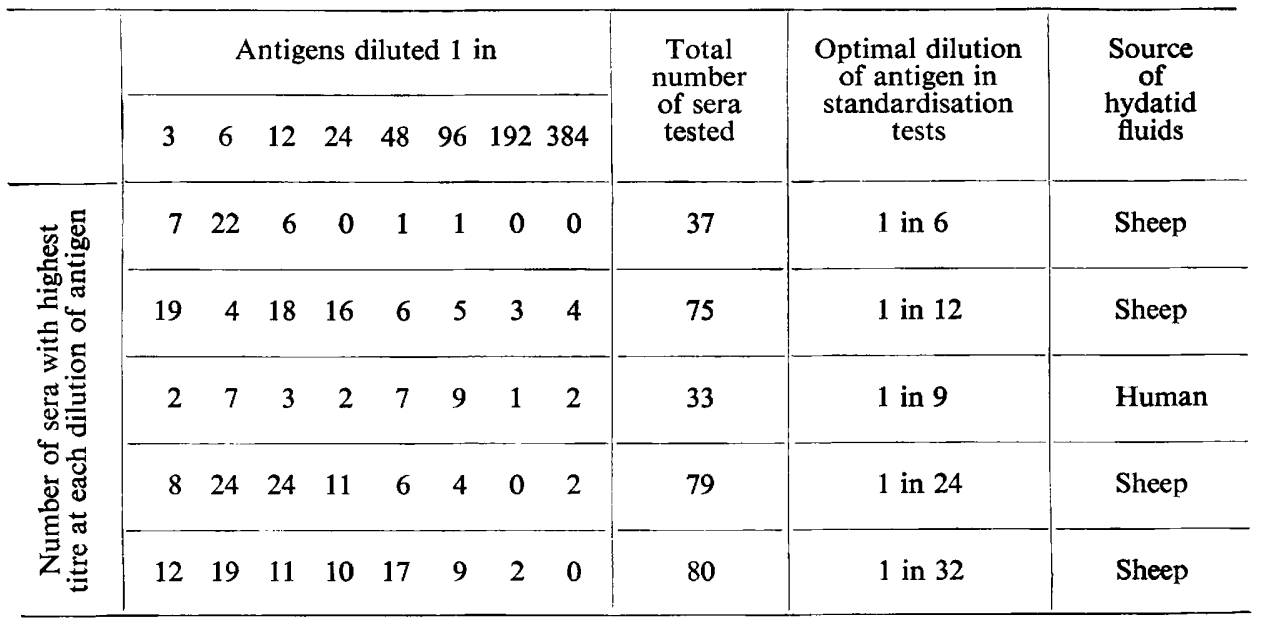

When positive sera were tested in chessboard titrations with different hydatid fluids (table VIII), all sera reacted with all fluids tested and, provided that the accepted titre was that given by the optimal dilution of hydatid fluid, all titres were similar. From table VIII it can also be noted that although the optimal dilution of a fluid was usually high with sera of high titre and low with sera of low titre, there were a number of instances in which a potent serum reacted best with a relatively high concentration of fluid, and a weak serum with a relatively low concentration of fluid. In two cases hydatid fluids, $\mathrm{H} 1$ and $\mathrm{H} 5$, showed lower optimal dilutions with their homologous sera than they did with some heterologous sera.

The results of the tests on sera from 129 surgically proven cases in which the site of the cyst was recorded are shown in table IX. In agreement with previous reports (Fairley, 1922; Garabedian, Matossian and Suidan, 1959; Jonathan, 1960; Arabatzis and Papapanagiotou, 1963; Abou-Daoud, 1965; Kagan et al., 1966), patients with cysts in the liver had the highest serum titres, and those with cysts outside the abdomen or thorax the lowest; cysts were found 
most commonly in the liver, and least often in muscle, bone, the nervous system and the eye.

\section{TABLE VIII}

Results of chessboard titrations of human sera each with several batches of hydatid fuid (reciprocal of dilution expressed as titre of serum and optimum of hydatid fluid)

\begin{tabular}{|c|c|c|c|c|c|c|c|c|}
\hline \multirow{2}{*}{ Serum } & \multirow{2}{*}{$\begin{array}{l}\text { Serum } \\
\text { titre with } \\
\text { all fluids } \\
\text { tested }\end{array}$} & \multicolumn{7}{|c|}{$\begin{array}{c}\text { Dilution of stated hydatid fluid reacting optimally in } \\
\text { chessboard titrations }\end{array}$} \\
\hline & & S2 & S3 & $\mathrm{H} 1 \dagger$ & $\mathrm{H} 2$ & H3 & H4 & H5* \\
\hline $\begin{array}{c}1 \\
2 \\
3 \\
4 \\
5 \\
6 \\
7 \\
8^{*} \\
9 \dagger \\
10 \\
11 \\
12 \\
13 \\
14 \\
15 \\
16 \\
17 \\
18 \ddagger\end{array}$ & $\begin{array}{c}16-32 \\
32-64 \\
64-128 \\
128-256 \\
32-64 \\
256-512 \\
256-512 \\
640-1280 \\
16 \\
8-16 \\
64-128 \\
64-128 \\
128 \\
64 \\
32 \\
64 \\
64 \\
512\end{array}$ & $\begin{array}{r}128 \\
16 \\
8 \\
8 \\
512 \\
32 \\
512 \\
\ldots \\
\ldots \\
8 \\
16 \\
32 \\
16 \\
16 \\
12 \\
4 \\
8 \\
512\end{array}$ & $\begin{array}{r}64 \\
4 \\
2 \\
8 \\
512 \\
4 \\
256 \\
4 \\
16 \\
2 \\
16 \\
16 \\
16 \\
6 \\
2 \\
4 \\
8 \\
\ldots\end{array}$ & $\begin{array}{r}4 \\
2 \\
2 \\
4 \\
64 \\
8 \\
128 \\
\ldots \\
4 \\
\ldots \\
4 \\
8 \\
8 \\
6 \\
2 \\
2 \\
4 \\
\ldots\end{array}$ & $\begin{array}{r}4 \\
2 \\
2 \\
4 \\
16 \\
4 \\
128 \\
\ldots \\
\ldots \\
\ldots \\
\ldots \\
\ldots \\
\ldots \\
\ldots \\
\ldots \\
\ldots \\
\ldots\end{array}$ & $\begin{array}{c}4 \\
4 \\
4 \\
6 \\
4 \\
8 \\
8 \\
\ldots \\
\ldots \\
\ldots \\
\ldots \\
\ldots \\
\ldots \\
\ldots \\
\ldots \\
\ldots \\
\ldots \\
64\end{array}$ & $\begin{array}{r}2 \\
2 \\
32 \\
4 \\
256 \\
32 \\
256 \\
\ldots \\
\ldots \\
\ldots \\
\ldots \\
\ldots \\
\ldots \\
\ldots \\
\ldots \\
\ldots \\
\geqq 1026\end{array}$ & $\begin{array}{r}8 \\
2 \\
2 \\
2 \\
256 \\
16 \\
256 \\
2 \\
\ldots \\
\ldots \\
\ldots \\
\ldots \\
\ldots \\
\ldots \\
\ldots \\
\ldots \\
\ldots\end{array}$ \\
\hline
\end{tabular}

S2 and S3 = Sheep hydatid fluids; $\mathrm{H} 1$ to $\mathrm{H} 5=$ human hydatid fluids; ${ }^{*} \dagger \ddagger=$ serum specimen and hydatid fluid from same patient; $\ldots=$ not tested. All sera came from surgically proven cases.

TABLE IX

Antibody titre in relation to site of cyst of 129 patients treated surgically

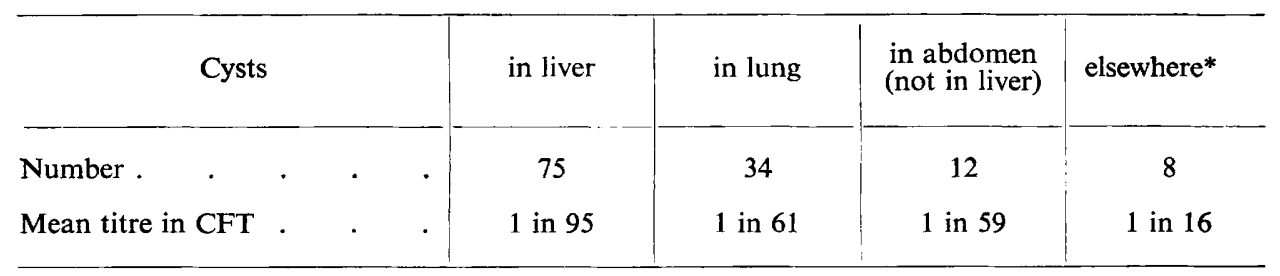

* Buttock, axilla, brain, thigh, muscle, spine, eye.

In routine tests on 3386 sera, a titre of 1 in 8 or more was obtained in 544 specimens. Table $\mathrm{X}$ shows that the largest number of these came from Greater London with 3.6 positive specimens annually per million of the population; the next largest came from Wales with 2.6 per million. Although Scotland had a higher percentage of positive sera as a proportion of all that were submitted, when the percentage was calculated according to the population of that country the incidence of diagnostic titres was similar to that found in specimens from the "rest of England". 
TABLE X

Positive results in complement-fixation tests $1957-67$, by region

\begin{tabular}{|c|c|c|c|c|c|c|}
\hline \multicolumn{3}{|c|}{ Region } & $\begin{array}{l}\text { Number of } \\
\text { sera with } \\
\text { CFT titres of } \\
1 \text { in } 8 \text { or more }\end{array}$ & $\begin{array}{l}\text { Positive tests } \\
\text { as percentage } \\
\text { of all tests } \\
\text { in region }\end{array}$ & $\begin{array}{c}\text { Estimated } \\
\text { population } \\
\text { (thousands) }\end{array}$ & $\begin{array}{l}\text { Annual rate } \\
\text { per million } \\
\text { population }\end{array}$ \\
\hline Greater & Idon & . & 296 & $20 \cdot 0$ & 8200 & $3 \cdot 60$ \\
\hline \multicolumn{3}{|c|}{ Wales, Hereford and Monmouth } & 67 & $21 \cdot 0$ & 2600 & $2 \cdot 60$ \\
\hline Scotland & . & . & 28 & $29 \cdot 5$ & 5200 & $0 \cdot 53$ \\
\hline Rest & . & . & 153 & $10 \cdot 5$ & 36,000 & 0.43 \\
\hline Total & . & . & 544 & $16 \cdot 0$ & 52,000 & $1 \cdot 04$ \\
\hline
\end{tabular}

\section{Discussion}

In these investigations, positive skin-test results were obtained in only 66 per cent. of patients with a cyst, in contrast with the high proportion of positive results usually reported in positive cases (table I) and with the high percentage of positive results obtained by CFT. Although both tests showed a high percentage of positive results in patients in whom no cyst was found at operation, little reaction to the skin test was found in healthy persons in Cardiganshire and there was little evidence of complement-fixing antibody in the control sera of those living in the London area.

A false negative skin-test result may occur if the injected dose of hydatid fluid contains an inadequate amount of a particular antigen required to promote a reaction in special cases (Bensted and Atkinson, 1953). This difficulty cannot readily be overcome since the test, in practice, cannot be made either quantitative or qualitative by employing a number of different hydatid fluids or dilutions of one fluid in skin tests on individual patients. This problem, however, is unlikely to have been the major cause of the low percentage of positive results in the present series, because there was a high percentage of positive results in patients in whom no cyst was found at operation. It is more likely to have been due to errors made either in the performance of the test or in the reading or interpretation of the results. The difficulties involved in obtaining consistent results in the reading of intradermal tests by different observers were made clear in the Medical Research Council Tuberculin Survey (Medical Research Council, 1952) in which a large single batch of antigen was used. In the investigations reported here, the intradermal tests were performed by some hundreds of medical practitioners who were obliged to use fluids from a variety of sources. Many were inexperienced in the performance of the test and the observers were 
handicapped because there are no well-defined measurements that constitute a significantly positive result.

The high percentage of positive CFT results was possible because of certain procedures adopted in the performance of the test: (i) the careful standardisation of hydatid fluid by chessboard titration to estimate the optimal dilution for use, the importance of which has been previously stressed (Sonntag, 1913, cited by Hiles, 1926a; Fairley, 1922; Goldsworthy, 1928; Dennis, 1937; Bensted and Atkinson); (ii) the selection of a concentration of complement and the time and temperature of its incubation with antigen and antibody to ensure a sensitive test; and (iii) the use of chessboard titrations with sera that showed atypical reactions in routine tests. There was also considerable advantage in having the tests all performed by a few experienced technicians and read mainly by one person.

The large number of positive results of both tests in patients in whom no cyst was found at operation reflects the type of patient investigated, for the majority were living or had lived in areas where the disease was endemic and some had a history of previous hydatid disease. In all cases it was appropriate to investigate for possible current hydatid infection. Many patients were to be operated upon regardless of the result of the tests, and the finding of no cyst at operation was no proof, of course, that hydatid disease was not present. As illustrated by the results of the skin test in the Breconshire group, several patients give a positive result in the absence of any known previous infection, whilst others give positive results in both tests because of residual immunity from previous infection. Only rarely would these positive results have been due to non-specific reactions for, although antigens present in hydatid fluids crossreact with antigens contained in other helminths (Morenas, 1929, 1932; Fairley, 1933; Chung and T'ung, 1939; Culbertson and Rose, 1939, 1941; Rose and Culbertson, 1939, 1940), such infections are not common in Britain. This assumption is further supported by the results of the control investigations; there was little evidence of complement-fixing antibody, even in those living in the London area, or of skin sensitivity in those living in Cardiganshire.

Once skin sensitivity is established in patients, it can last for many years and the significance of a positive intradermal test in the diagnosis of secondary infection becomes quite uncertain. On the other hand, the CFT technique can be made qualitative and quantitative so that a more precise estimation of antibody is possible. The test is reliable in the diagnosis of primary infection and because the presence of complement-fixing antibodies, in general, denotes current or recent infection (Fairley, 1922; Bensted and Atkinson; Magath, 1959 ) it is of considerable help in the diagnosis of recurrence of the disease. Repeated tests on surgically treated patients demonstrate the decline in antibody until no more is detected or until a residual static titre is established. The knowledge of this static titre is of importance, for it enables a more reliable interpretation to be made of low titres of 1 in 8 to 1 in 32 which may be found in subsequent serological investigations on these patients.

In cases of primary infection, the diagnostic significance of titres of 1 in 2 and 1 in 4 is doubtful, for 16 and 9 per cent. respectively of healthy persons in 
the control series, and 14 and 19 per cent. respectively of patients with cysts had these same titres. Many titres of 1 in 8 and certainly titres of 1 in 16 or more are significant. A low titre of antibody may occur in human infections if the cyst is deficient in scolices and therefore in antigenic content, or if it is surrounded by fibrous or calcified tissue which prevents the leakage of antigen into the circulation. Occasionally it occurs because of failure by the host to form antibody. Low titres will also be present in persons living in endemic areas but without detectable infection. Of the 3386 CFTs that we performed, 62 per cent. were negative and 16 per cent. gave titres of 1 in 8 or more. In the remaining 20 per cent., more extensive investigations to confirm the diagnosis were required, and on rare occasions repetition with a further specimen of serum helped clarification.

Thus, our evaluation of the two tests used in these investigations for the diagnosis and prognosis of hydatid disease indicates that the CFT is preferable, provided it is properly standardised, made sensitive and done in laboratories experienced in its performance and interpretation. The intradermal test, because of its inherent disadvantages and the difficulties related to its performance, should not generally be used for this purpose. It can, however, be regarded as a reliable means of estimating the prevalence of infection, past or present, in a community in which other helminths are not commonly found, and for this purpose, because the test should be as sensitive as possible, the most potent fluids should be used. There have been several reports of satisfactory results with fluids from infected persons (Durand, 1909, Kreuter, 1909, and Dobrotine, 1910, all cited by Hiles, 1926a; Bensted and Atkinson; Magath). Our findings, however, agree with the results of those who found sheep fluid more sensitive (Putzu, 1909, and Abrikosaw, 1913, cited by Hiles, 1926a; Weinberg, 1913, cited by Fairley, 1922; Kellaway and Fairley, 1932; Graña, 1945). A diluted potent antigen will probably give more reliable results by eliminating minor antigens that cross-react with antigens present in other helminths.

Chessboard titrations not only increased the number of positive results by obtaining a reading with the optimal dilution of a fluid; they also afforded a means of demonstrating the antigenic complexity of hydatid fluid, which has already been observed by others employing different techniques (Kagan and Norman, 1961, 1963; Norman, Kagan and Chordi, 1964; Chordi and Kagan, 1965; Norman and Kagan, 1966; Norman, Kagan and Allain, 1966). From the variation in optimal dilution exhibited by each fluid with the individual sera (table VII), it was concluded that each fluid contained a number of different antigens.

The results of the chessboard titrations of each serum with a number of different fluids (table VIII) provide evidence that, in accordance with the concept of optimal ratios (Dean and Webb, 1926), the concentration of the antigens contained in the fluids varied. This was shown by the fact that individual sera reacted to titre with different dilutions of the different batches of fluid. When a fluid containing a mosaic of antigens is used in chessboard titrations, the picture observed represents not only optimal and suboptimal reactions between different dilutions of serum and one antigen, but also similar reactions between 
a number of different antigen-antibody complexes, and the optimum combination of the whole fluid with a serum is seen at the dilutions of the antigen and antibody components that produce the highest titre. The most potent fluids were those that showed high reactivity in many dilutions with a positive serum in contrast to the less potent fluids which reacted to serum titre at only a few dilutions. It is not clear at present why a higher concentration of a human hydatid fluid is sometimes required to produce an optimal reaction with potent homologous serum than the concentration required for optimal activity with serum of lower titre from another patient. Factors involved in this phenomenon are likely to include: the concentration and number of antigens present in the infecting cyst, the host antibody response during the course of the infection, and the stage of the disease at which the patient's serum is tested. More human hydatid fluids and their homologous sera are now being studied to elucidate this observation further.

Hydatid disease is not notifiable in Britain and its incidence is therefore not exactly known. However, as the Standards Laboratory is one of the main centres performing CFTs for the diagnosis of this disease, the frequency of positive results with sera submitted from different regions possibly reflects local prevalence of infection. Although infections contracted in Britain probably occur most commonly in the central counties of Wales where Cook (1964) found infestation in 23 per cent. of the dog population, the highest incidence of infection seems to be in Greater London. This can be accounted for by the presence in London of large numbers of immigrants from areas such as Cyprus, Greece and India where hydatid disease is endemic; moreover, a number of patients from other parts of the country go to London for treatment. There appears to be no marked difference in the incidence of the disease between Scotland and the rest of England, although there seems to be a somewhat greater selection made when specimens are submitted from Scotland.

\section{SUMMARY}

Results obtained with intradermal (Casoni) and complement-fixation tests (CFT) in cases of suspected hydatid disease in the United Kingdom studied over a period of $10 \mathrm{yr}$ are reported, and a reassessment is made of the reliability of each test for diagnosis and prognosis. Because of a number of disadvantages, the Casoni test is not recommended for diagnosing current infection. It is useful, however, for indicating past or present infection in a community, and in these circumstances a potent antigen, capable of being used diluted, should be employed.

The CFT, properly standardised, is shown to be reliable for diagnosis and prognosis and for these purposes it is the test of choice. Sensitivity of the test is enhanced by chessboard titrations and by these means information is obtained relating to the antigenic complexity of hydatid fluids. Studies of CFT results have confirmed that cysts are found most commonly in the liver where they promote the highest titres. From the number of positive results, the greatest incidence of infection appears to be in the Greater London 
area, but the highest rate of infection acquired in Britain probably occurs in Wales.

I should like to express my grateful thanks to the many medical practitioners who have submitted specimens of sera, reported results of skin tests, and sent generous supplies of human and sheep hydatid fluid used in these investigations; to Dr R. W. Riddell of the Brompton Hospital, London, for initially investigating the use of diluted hydatid fluid in intradermal tests; to Mr John Foreman, Mr William Bradley, Miss Anne Rawlinson (Mrs Pauls) and Mr John Essex for excellent technical assistance, and to Mrs Dorothy Marriner for valuable secretarial help.

\section{REFERENCES}

Abou-Daoud, K. T. . . . . . . . . 1965. Amer. J. Trop. Med. Hyg., 14, 760.

Arabatzis, G., and Papapanagiotou, J. 1963. Bull. Wld Hith Org., 28, 266.

Bensted, H. J., AND AtKInson, J. D. . 1953. Lancet, 1, 265.

Bradstreet, C. M. Patricia, and 1962. Mon. Bull. Minist. Hlth, 21, 96.

TAYLOR, C. E. D.

CASONI, T.

Chordi, A., and Kagan, I. G.

1911. Folia clin. chim. microsc., Salsomaggiore, 4, 5.

. . 1965. J. Parasit., 51, 63.

Chung, H.-L., ANd T'ung, T. . . . . 1939. Trans. Roy. Soc. Trop. Med. Hyg., 32, 697.

COOK, B. R.

Culbertson, J. T., AND Rose, H. M.

1964. Ann. Trop. Med. Parasit., 58, 147.

" " " " $\quad$. 1941. J. Clin. Invest., 20, 249.

DEAN,"H. R., AND WEBB, R. A. . . . 1926. J. Path. Bact., 29, 473.

DenNis, E. W. . . . . . . . . . . 1937. J. Parasit., 23, 62.

Fairley, K. D., and Kellaway, C. H. . 1933. Austral. N.Z. J. Surg., 2, 236.

FaIrLeY, N. H. . . . . . . . . 1922. Q.J. Med., 15, 244.

1933. Trans. Roy. Soc. Trop. Med. Hyg., 27, 360.

Garabedian, G. A., Matossian, R. M., 1959. Amer. J. Trop. Med. Hyg., 8, 67. AND SUIDAN, F. G.

GHEDINI, G.

GOLDSWORTHY, N $\mathrm{E}^{\cdot} \cdot \cdot \cdot \cdot \cdot \cdot$

GraÑa, A.

1906. Gazz. Osp. Clin., 27, 1616.

1928. J. Path. Bact., 31, 435.

1945. Archos urug. Med. Cirug., 26, 538: abstr. in Trop. Dis. Bull., 1946, 43, 139.

Hariri, M. N., Schwabe, C. W., AND KousSA, $M$.

HILES, I. .

1965. Amer. J. Trop. Med. Hyg., 14, 592.

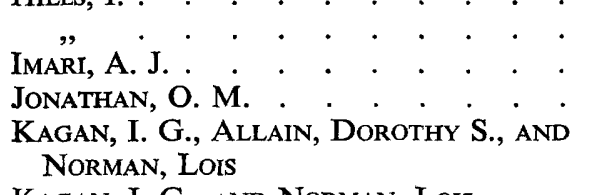

Kagan, I. G., AND Norman, LoIs .

1926a. J. Helminth., 4, 143.

1926b. Proc. Roy. Soc. Med., $20,708$.

1962. Amer. J. Trop. Med. Hyg., 11, 481.

1960. Br. Med.J., 1, 1246.

1959. Amer. J. Trop. Med. Hyg., 8, 51.

1961. Ibid., 10, 727.

1963. Ann. N.Y. Acad. Sci., 113, 130.

KaGan, I. Ğ., OsImani, J. "J., Varela, J. C., AND Allain, Dorothy $\mathrm{S}$.

Kellaway, C. H. . . . . $\cdot$. $\cdot$.

Magath, T. B.

1966. Amer. J. Trop. Med. Hyg., 15, 172.

1925. Med.J. Austral., 1, 417.

1932. Ibid., 1, 340.

1959. Amer.J. Clin. Path., 31, 1.

Medical Research Council Tuber- 1952. Lancet, 1, 775. CULIN SURVEY COMMITTEE

Mirdamadi, H., ANd SaAdatzadeh, H. 1968. Hlth Lab. Sci., 5, 79. 


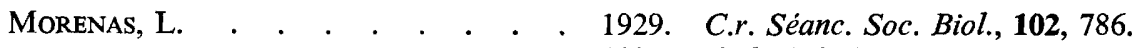

"

Myers, N. A. - . . . . . . . 1960. Med. J. Austral., 1, 806.

Norman, Lois, and Kagan, I. G. . 1966. J. Immun., 96, 814.

Norman, LoIS, KaGan, I. G., AND 1966. Ibid., 96, 822.

Allain, Dorothy S.

Norman, Lois, Kagan, I. G., AND 1964. Amer. J. Trop. Med. Hyg., 13, 816. CHORDI, A.

Rose, H. M., and Culbertson, J. T. 1939. Proc. Soc. Exp. Biol. Med., 41, 426.

" " " $\quad " \quad$. 1940. J. Amer. Med. Assoc., 115, 594.

Tномаs, D. ." . . . . . . . . . 1966. M.D. Thesis, Univ. Liverpool. 